\title{
Lung Cancer pM1c TNM Finding v8
}

National Cancer Institute

\section{Source}

National Cancer Institute. Lung Cancer pM1c TNM Finding v8. NCI Thesaurus. Code C136443.

Lung cancer with multiple extrathoracic metastases in a single organ or in multiple organs. (from AJCC 8th Ed.) 